\title{
Attenuated expression of tenascin-c in ovalbumin-challenged STAT4-/- mice
}

\author{
Anna Meuronen ${ }^{1 *}$, Piia Karisola ${ }^{2}$, Marina Leino ${ }^{2}$, Terhi Savinko ${ }^{2}$, Kristiina Sirola $^{2}$, Marja-Leena Majuri ${ }^{2}$, Päivi Piirilä3 \\ Ismo Virtanen', Mika Mäkelä4, Annika Laitinen', Lauri A Laitinen', Harri Alenius²
}

\begin{abstract}
Background: Asthma leads to structural changes in the airways, including the modification of extracellular matrix proteins such as tenascin- $C$. The role of tenascin- $C$ is unclear, but it might act as an early initiator of airway wall remodelling, as its expression is increased in the mouse and human airways during allergic inflammation. In this study, we examined whether Th1 or Th2 cells are important regulators of tenascin- $C$ in experimental allergic asthma utilizing mice with impaired Th1 (STAT4-/-) or Th2 (STAT6-/-) immunity.

Methods: Balb/c wildtype (WT), STAT4-/- and STAT6-/- mice were sensitized with intraperitoneally injected ovalbumin (OVA) followed by OVA or PBS airway challenge. Airway hyperreactivity (AHR) was measured and samples were collected. Real time PCR and immunohistochemistry were used to study cytokines and differences in the expression of tenascin-C. Tenascin-C expression was measured in human fibroblasts after treatment with TNF- $\alpha$ and IFN- $\gamma$ in vitro.

Results: OVA-challenged WT mice showed allergic inflammation and AHR in the airways along with increased expression of TNF- $\alpha$, IFN- $\gamma$, IL-4 and tenascin-C in the lungs. OVA-challenged STAT4-/- mice exhibited elevated AHR and pulmonary eosinophilia. The mRNA expression of TNF- $\alpha$ and IFN- $\gamma$ was low, but the expression of IL-4 was significantly elevated in these mice. OVA-challenged STAT6-/- mice had neither AHR nor pulmonary eosinophilia, but had increased expression of mRNA for TNF- $\alpha$, IFN- $\gamma$ and IL-4. The expression of tenascin-C in the lungs of OVAchallenged STAT4-/- mice was weaker than in those of OVA-challenged WT and STAT6-/- mice suggesting that TNF- $\alpha$ and IFN- $\gamma$ may regulate tenascin-C expression in vivo. The stimulation of human fibroblasts with TNF- $\alpha$ and IFN- $\gamma$ induced the expression of tenascin-C confirming our in vivo findings.
\end{abstract}

Conclusions: Expression of tenascin- $C$ is significantly attenuated in the airways of STAT4-/- mice, which may be due to the impaired secretion of TNF- $\alpha$ and IFN- $\gamma$ in these mice.

\section{Background}

Allergic asthma is an inflammatory disorder of the airways characterised by episodes of airway obstruction and wheezing. Th2 cells secreting IL-4, IL-5 and IL-13 have been identified in the airways of asthmatic patients. In humans, Th2 cytokines produced in the respiratory tract lead to airway eosinophilia, high levels of serum IgE, and mast cell activation [1], which are believed to contribute to pathologies such as airway hyperresponsiveness (AHR), epithelial damage and mucus secretion. Accumulating evidence suggests, however, that airway

\footnotetext{
* Correspondence: anna.meuronen@helsinki.fi

${ }^{1}$ Institute of Biomedicine/Anatomy, University of Helsinki, Biomedicum, Helsinki, Finland

Full list of author information is available at the end of the article
}

inflammation alone may not explain the irreversible progression of the disease in some patients despite antiinflammatory therapy [2]. Therefore, in recent years, greater effort has focused on remodelling of the airways, which entails thickening of the airway wall, depositing extracellular matrix (ECM) proteins, and altering their epithelial composition [1].

The expression of tenascin- $C$ is increased in the airway wall in asthma. Tenascin-C belongs to the matricellular proteins and is widely expressed during embryonic development, but is generally lacking in adult tissues. Tenascin-C contributes to cell adhesion, migration and proliferation [3], participates in lung development and remodelling $[3,4]$, and is necessary for branching morphogenesis of the bronchial tree $[4,5]$. Tenascin-C is
C Biomed Central

() 2011 Meuronen et al; licensee BioMed Central Ltd. This is an Open Access article distributed under the terms of the Creative Commons Attribution License (http://creativecommons.org/licenses/by/2.0), which permits unrestricted use, distribution, and reproduction in any medium, provided the original work is properly cited. 
down-regulated after alveolarization [5-7], and its expression is sparse or absent under the bronchial epithelium in healthy adults [8]. We have previously demonstrated that human patients with asthma show elevated levels of tenascin- $\mathrm{C}$ in the $\mathrm{BM}$ of the bronchi quite early after diagnosis $[8,9]$. However, very little is known about the regulation of tenascin- $\mathrm{C}$ or its role in asthma in vivo.

STAT6 and STAT4 are members of the signal transducer and activator of transcription (STAT) family of transcription factors. STAT6 is critical in mediating the effects of IL-4 and IL-13 [10,11]. Thus, STAT6 is important in Th2 lymphocyte differentiation, allergic responses such as AHR, and combating parasitic infections in mice. STAT6 induces the expression of IL-4 and down-regulates the production of IFN- $\gamma$ [12]. STAT6 has been suggested as a possible new target for asthma treatment $[13,14]$. STAT4, on the other hand, mediates the effects of IL-12 on gene transcription, thereby promoting Th1 lymphocyte differentiation, and IFN- $\gamma$ is one of its main targets [12,15]. Interestingly, STAT4 seems to also play an important role in Th2 responses [16,17].

We investigated whether one of these two distinct parts of adaptive immunity, Th1 or Th2, might play an independent role in the regulation of tenascin- $\mathrm{C}$ expression in experimental allergic asthma in the lung. We explored the contribution of impairment in Th1 and Th2 immunity to tenascin-C expression using STAT4-/and STAT6 -/- mice. Furthermore, we examined the expression of Th1 (IFN- $\gamma$ ) cytokines, Th2 (IL-4) cytokines and TNF- $\alpha$, which are all important in asthma [1] and are possible regulators of tenascin- $\mathrm{C}$ expression [9,18-21]. The results were tested and confirmed with human cells in vitro.

\section{Methods}

\section{Animals}

$\mathrm{BALB} / \mathrm{c}$ female mice, age 6 to10 weeks and free of specific pathogens, were obtained from $M \& B$, Denmark. STAT4-/- and STAT6-/- mice, both of Balb/c background, were purchased from Jackson Laboratory (Bar Harbor, Maine, USA). All the mice were housed under specific pathogen-free conditions and maintained on an ovalbumin-free diet at the Finnish Occupational Health Institute. All the experiments were approved by the State Provincial Office of Southern Finland.

\section{Sensitisation and airway challenge}

On days 0 and 14, all mice were sensitised with an intraperitoneal (i.p) injection of $50 \mu \mathrm{g}$ of ovalbumin (OVA) (Grade V; Sigma, St. Louis, MO, USA) emulsified in $2 \mathrm{mg}$ of aluminium hydroxide in a total volume of $100 \mu \mathrm{l}$. The mice were intranasally challenged with $50 \mu \mathrm{l}$ of PBS (controls) or with $50 \mu \mathrm{g}$ of OVA diluted in $50 \mu \mathrm{l}$ of PBS for three days (days 28, 29 and 30) under isoflurane anaesthesia with spontaneous breathing. Eight mice were assigned to each group.

\section{Determination of airway responsiveness}

Airway responsiveness was assessed 24 hours after the last OVA airway challenge. A single-chamber wholebody plethysmograph system obtained from Buxco Technologies (Troy, NY, USA) was used as described [22]. Briefly, mice were placed unrestrained into a chamber and exposed for five min to nebulised PBS and subsequently to increasing concentrations of methacholine (MCh) (Sigma-Aldrich, UK) in PBS using an AeroSonic 5000 D ultrasonic nebuliser (DeVilbiss, Somerset, PA). Recordings were taken after each nebulisation for five min. The enhanced pause (Penh) values for each fivemin sequence were evaluated and expressed for each MCh concentration. Baseline Penh values did not differ significantly between groups.

\section{Sample collections and lung preparations}

The mice were killed by isoflurane overdose and the blood was drained from the hepatic vein. The chest cavity was opened, and the lungs were lavaged with $800 \mu \mathrm{l}$ of PBS via the tracheal tube. The bronchoalveolar lavage (BAL) sample was cytospun on a slide, the cells were stained with MayGrünwald-Giemsa (MGG) stain, and the cell differentials were counted under a light microscope. The left lung was removed, quick-frozen and stored at $-70^{\circ} \mathrm{C}$ for RNA isolation. For the immunohistological examination, half of the right lung was embedded in TissueTek OCT Compound (Sakura Finetek Europe B.V., The Netherlands), quick-frozen and stored at $-70^{\circ} \mathrm{C}$. The other half was fixed in paraformaldehyde and embedded in paraffin.

\section{Real-time quantitative RT-PCR assay}

Total RNA from the lungs and cells was extracted using Eurozol Reagent (EuroClone, Italy) according to the manufacturer's instructions. Total RNA was quantified with spectrophotometry (Nanodrop, Nanodrop Technologies, Wilmington, DE, USA). The RNA was reversetranscribed into cDNA with a High Capacity cDNA Reverse Transcription Kit (Applied Biosytems, Foster City, CA, USA). The real-time quantitative polymerase chain reaction (PCR) was performed with an Applied Biosystems 7500 Fast Real-Time PCR System, according to the manufacturer's instructions. PCR primers and probes were obtained as predeveloped assay reagents (cytokines and $18 \mathrm{~S}$ rRNA) or were generated (tenascin-C) with PrimerExpress version 1.5 software and ordered from Applied Biosystems. The primer and probe sequences for tenascin-C were as follows: forward primer 5'-ACC ATG 
CTG AGA TAG ATG TTC CAA A-3', reverse primer 5'CTT GAC AGC AGA AAC ACC AAT CC-3', and probe 5'-ACC ACA CTC ACA GGT CTA AGG CCC GG-3'. The accumulation of PCR products was detected directly by monitoring the increase in fluorescence of the reporter dye. The signals were standardised to the internal passive reference ROX to exclude non-PCR-related fluctuations in the fluorescence. In addition, FAM signals were standardised to the endogenous reference rRNA $18 \mathrm{~S}$ to normalise the quantification of mRNA targets for differences in total RNA.

\section{Immunohistochemistry}

Quick-frozen samples were used for immunofluoresence. Monoclonal rat anti-mouse antibody clone MTn-12 from Sigma-Aldrich (1:200) served to detect tenascin-C and fluorescein (FITC)-conjugated anti-rat IgG (Jackson ImmunoResearch Laboratories Europe, UK) (1:100) served as a secondary antibody. The intensity of immunoreactivity for tenascin- $\mathrm{C}$ was graded in random order slide by slide. All the groups were graded at the same time. This resulted in grades from 0-4 $(0=$ no reactivity, 1 = weak reactivity, $2=$ intermediate reactivity, 3 = strong reactivity, $4=$ very strong reactivity). All samples were coded, and the codes were broken after completion of all the tests.

\section{Cells}

MRC-9 cells were obtained from ATCC (Manassas, VA, USA). The cells were cultured in MEM supplemented with $10 \%$ FBS, $2 \mathrm{mM}$ glutamine, $0.1 \mathrm{mM}$ nonessential amino acids, $1.5 \mathrm{~g} / \mathrm{L}$ of sodium pyruvate and antibiotics (Gibco, Invitrogen, Life Technologies, Carlsbad, CA, USA) at $37^{\circ} \mathrm{C}$ in $5 \% \mathrm{CO}_{2}$. Cells were stimulated with TNF- $\alpha(10 \mathrm{ng} / \mathrm{ml})$ (Biosource International, Camarillo, $\mathrm{CA}, \mathrm{USA})$ at $37^{\circ} \mathrm{C}$ for three and nine hours.

Primary human dermal fibroblasts isolated from adult skin were purchased from Gibco and cultured in Medium 106 (Gibco) supplemented with LSGS (Low serum growth supplement) and antibiotics (Gibco) at $37^{\circ} \mathrm{C}$ in $5 \% \mathrm{CO}_{2}$. Cells were stimulated with TNF- $\alpha(20 \mathrm{ng} / \mathrm{ml})$, IFN- $\gamma$ (500 IU/ml, Immuno Tools, Friesoythe, Germany) and with a combination of TNF- $\alpha$ and IFN- $\gamma$ for 2,6 and 18 hours.

\section{Western blotting}

Tenascin-C protein was analyzed by Western blot from whole-cell extracts and concentrated cell supernatants. Human primary fibroblasts stimulated with the combination of TNF- $\alpha$ and IFN- $\gamma$ for $18 \mathrm{~h}$ were lysed in protein lysis buffer containing $10 \mathrm{mM}$ Tris (pH7.4), $150 \mathrm{mM} \mathrm{NaCl}$, and 25\% ethylene glycol supplemented with complete mini protease inhibitor mixture (Roche
Diagnostic, Indianapolis, IN). The cell extract was homogenized with ultrasound sonicator (Sanyo Electronics, San Diego, CA). Total protein concentrations were determined with Bio-Rad Dc Protein Assay (Bio-Rad Laboratories, Hercules, CA) according to the manufacturer's instructions. $20 \mu \mathrm{g}$ of protein from lysed cell extracts and 7,5 $\mu \mathrm{l}$ of concentrated cell culture supernatants were separated with SDS-PAGE on $12 \%$ gels and transferred onto Immobilon-P Transfer Membranes (Millipore). Membranes were blocked with 5\% non-fat milk in PBS and exposed to monoclonal mouse antihuman antibody 100EB2 recognizing tenascin-C [23]. After this, membrane was incubated with HRP-conjugated polyclonal goat anti-mouse immunoglobulins (Dako Cytomation). Proteins were visualized by Luminescent Image Analyzer (Image Quant LAS4000mini, GE Healthcare, Sweden). Total protein in the membrane was stained with SYPRO Ruby Protein Blot Stain (BioRad Laboratories).

\section{Statistical Analysis}

The data were analysed with GraphPadPrism Software (GraphPad Software, Inc., CA, USA). Single-group comparisons were performed with the Mann-Whitney U-test or Student's t-test when appropriate. Values for measurements are expressed as the mean \pm the standard error of the mean (SEM). P values $<0.05$ were considered significant.

\section{Results}

Tenascin-C levels are significantly elevated in the airways of ovalbumin-sensitised and challenged mice

A significant and prominent influx of eosinophils, lymphocytes and neutrophils in BAL was observable in OVA-challenged WT mice, whereas no eosinophils and only a few lymphocytes and neutrophils appeared in the BAL of the control mice (Figure 1A). Bronchial reactivity to inhaled methacholine was significantly higher in the OVA-challenged mice than in the controls (Figure 1B). The mRNA levels of proinflammatory cytokine TNF- $\alpha$, Th2 cytokine IL- 4 and Th1 cytokine IFN- $\gamma$ were significantly higher in the lung tissue of the OVA-challenged WT mice (Figure 1C). All these results indicate that our mouse model presents an acute allergic asthmatic response in the airways.

Tenascin- $C$ mRNA levels were significantly higher in the lung tissue of the OVA-challenged WT mice than in that of the PBS-challenged mice (Figure 2A). Tenascin-C immunoreactivity was weak and sparse in the control mice, although some staining was occasionally detected in the bronchial veins, the basal layer of the epithelium, and the smooth muscle beneath the bronchial epithelium (Figure 2B). In the OVA-challenged WT mice, 


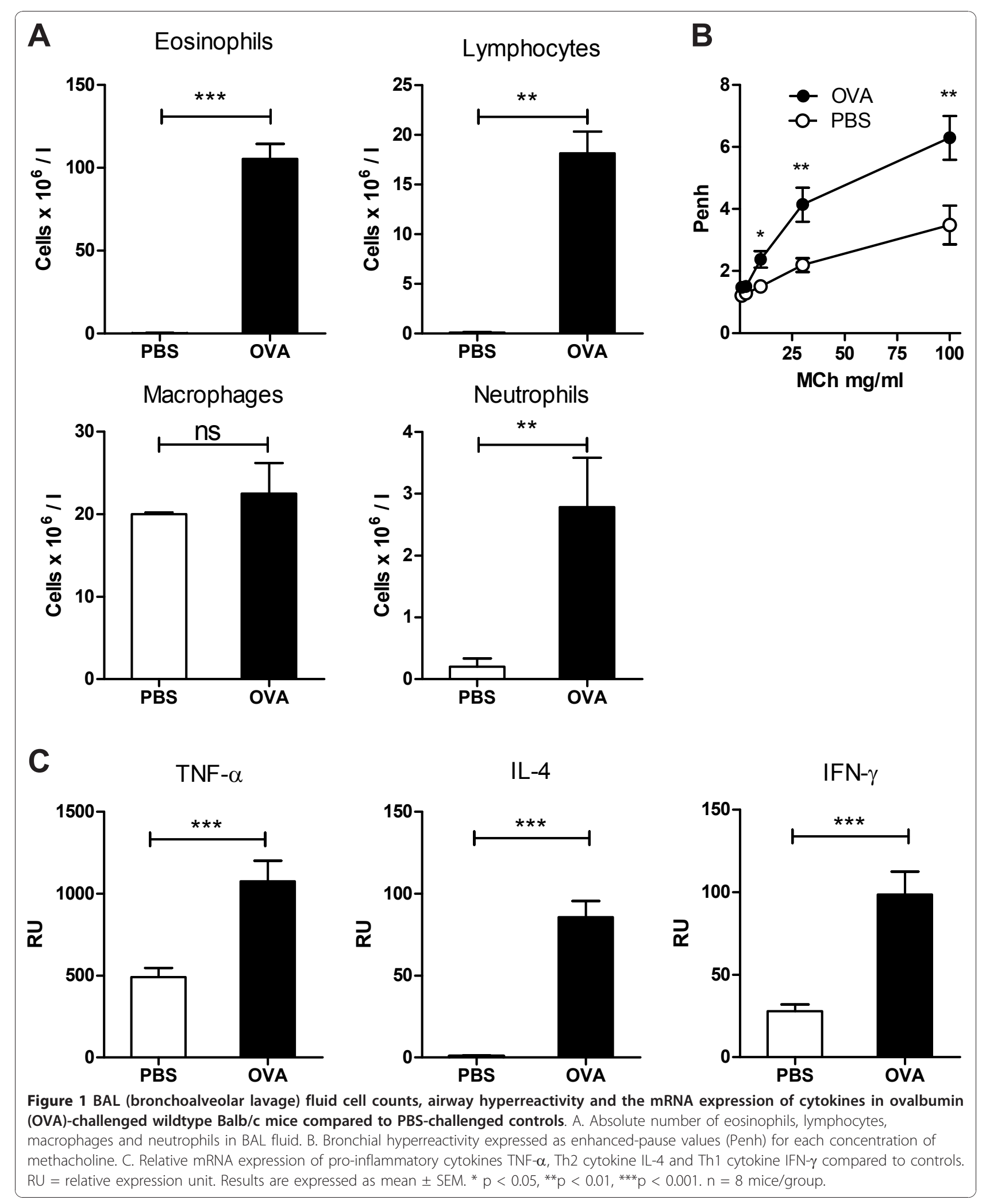




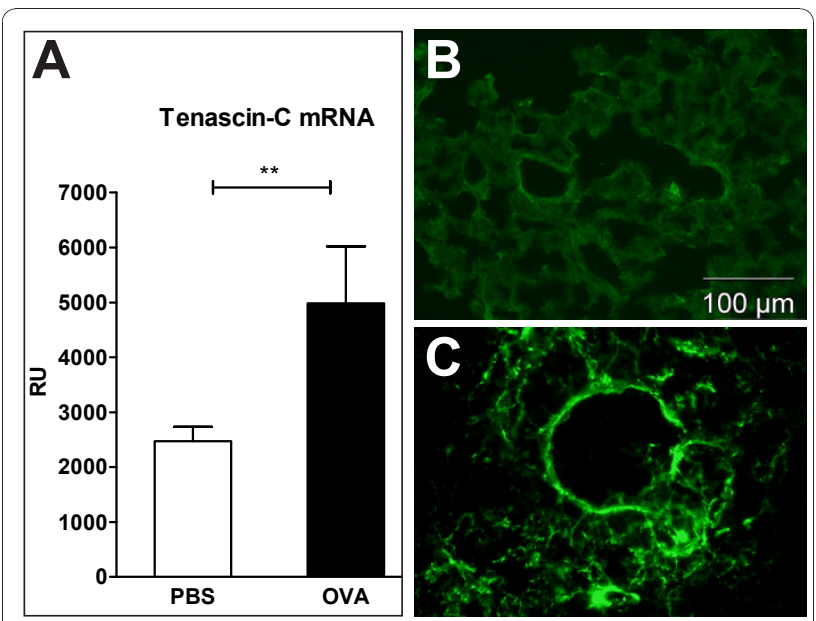

Figure $\mathbf{2}$ Tenascin-C expression in wildtype mice. A. The relative mRNA expression of tenascin- $C$ in the lung of ovalbuminchallenged and control mice. B-C. Immunofluoresence. The immunoreactivity of tenascin- $C$ in the lungs of control (B) and ovalbumin-challenged mice $(C)$. The lung parenchyma was stained brightly with tenascin- $C$ in the ovalbumin-challenged mice, but not in the control mice. All the mice showed sparse and faint immunoreactivity to tenascin- $C$ in the veins and bronchial smooth muscle. The bronchial basement membrane tested negative for tenascin- $C$ in both groups. $R U=$ relative expression unit. Results are expressed mean \pm SEM. ${ }^{* *} p<0.01$, ${ }^{* * *} p<0.001$. $n=8$ mice/ group.

immunoreactivity for tenascin- $C$ was strongly upregulated in the alveolar structures and was evident in small spots throughout the parenchyma (Figure 2C). The larger veins were extremely immunoreactive in places in the WT mice (not shown), whereas immunoreactivity for tenascin- $\mathrm{C}$ in the bronchial $\mathrm{BM}$ was negative in all groups.

Tenascin-C levels are significantly reduced in OVAchallenged STAT4-/- mice but normal in STAT6-/- mice The number of BAL eosinophils was significantly higher in the OVA-challenged STAT4-/- mice than in the PBSchallenged controls, with only a minor significant increase in the number of lymphocytes and neutrophils. There was also a minor significant decrease in the number of macrophages (Figure 3A). In contrast, an increase in the number of airway lumen eosinophils was minimal in the OVA-challenged STAT6-/- mice, but the influx of lymphocytes was comparable to that in the WT mice (Figure 3B). The number of neutrophils also was increased. Airway reactivity to methacholine was significantly stronger in the OVA-challenged STAT4-/- mice than in the PBS-challenged controls (Figure 3C). Compared to the PBS-challenged controls, the OVAchallenged STAT6-/- mice showed no airway hyperreactivity (Figure 3D). The expression of mRNA for major Th2 cytokine IL-4 was significantly elevated in the lung tissue of the OVA-challenged STAT4-/- mice, but we found no significant induction of proinflammatory cytokine TNF- $\alpha$ or Th1 cytokine IFN- $\gamma$ (Figure 4). The mRNA expression of TNF- $\alpha$, IFN- $\gamma$ and IL-4, however, was significantly higher in the OVA-challenged STAT6-/- mice than in the PBS-challenged controls (Figure 4).

The expression of tenascin-C mRNA in the lung tissue of the OVA-challenged STAT4-/- mice remained unchanged and was comparable to that of the control mice (Figure 5A). In contrast, the expression of tenascin-C was significantly higher in the OVA-challenged than in the PBS-challenged STAT6-/- mice (Figure 5A). In lung sections, tenascin- $C$ immunoreactivity was negative in the PBS-challenged STAT4-/- and STAT6-/mice (Figure 5B and 5C respectively). The OVA-challenged STAT4-/- mice (Figure 5D) showed weaker immunoreactivity to tenascin-C than did their WT (Figure 2C) and STAT6-/- counterparts (Figure 5E). The localisation of immunoreactivity was quite similar in all the groups except that STAT4-/- and STAT6-/- mice had no OVA-induced tenascin- $\mathrm{C}$ expression in the veins as the WT mice did. Immunoreactivity to tenascin-C was strongly up-regulated in the alveolar structures and was found in small spots throughout the parenchyma of the OVA-challenged mice in the STAT6-/-group, corresponding to that of the WT mice. Semi-quantitative analysis of immunoreactivity for tenascin- $C$ in the lung biopsies also showed diminished induction of tenascin- $C$ expression by ovalbumin in STAT4-/- mice compared to WT and STAT6-/- mice (Figure 5F).

\section{TNF- $\alpha$ stimulation triggers enhanced levels of tenascin-C from the cultured human lung fibroblasts}

Our in vivo studies showed that tenascin- $C$ expression was severely blunted in the airways of the OVA-challenged STAT4-/- mice. Moreover, the expression of major proinflammatory cytokine TNF- $\alpha$ was impaired in the lung tissue of the STAT4-/- mice. We therefore anticipated that impaired tenascin-C expression might stem from a lack of TNF- $\alpha$ stimulation in the airways of the OVA-challenged STAT4-/- mice. Indeed, the elevated expression of tenascin-C mRNA was evident in human lung fibroblasts (MRC-9) after stimulation with recombinant TNF- $\alpha$ (Figure 6A). This TNF- $\alpha$-induced expression was timedependent, peaking at $9 \mathrm{~h}$.

In order to show that this increase in tenascin- $C$ expression is not an MRC-9-specific phenomenon, we performed similar stimulations with human primary fibroblasts in which TNF- $\alpha$ also enhanced the expression of tenascin- $C$ mRNA (Figure 6B). When the primary cells were cultured in the presence of TNF- $\alpha$ and with the major Th1 cytokine, IFN- $\gamma$, the expression of tenascin-C mRNA appeared to increase in a cumulative manner (Figure 6B). Further, the protein 

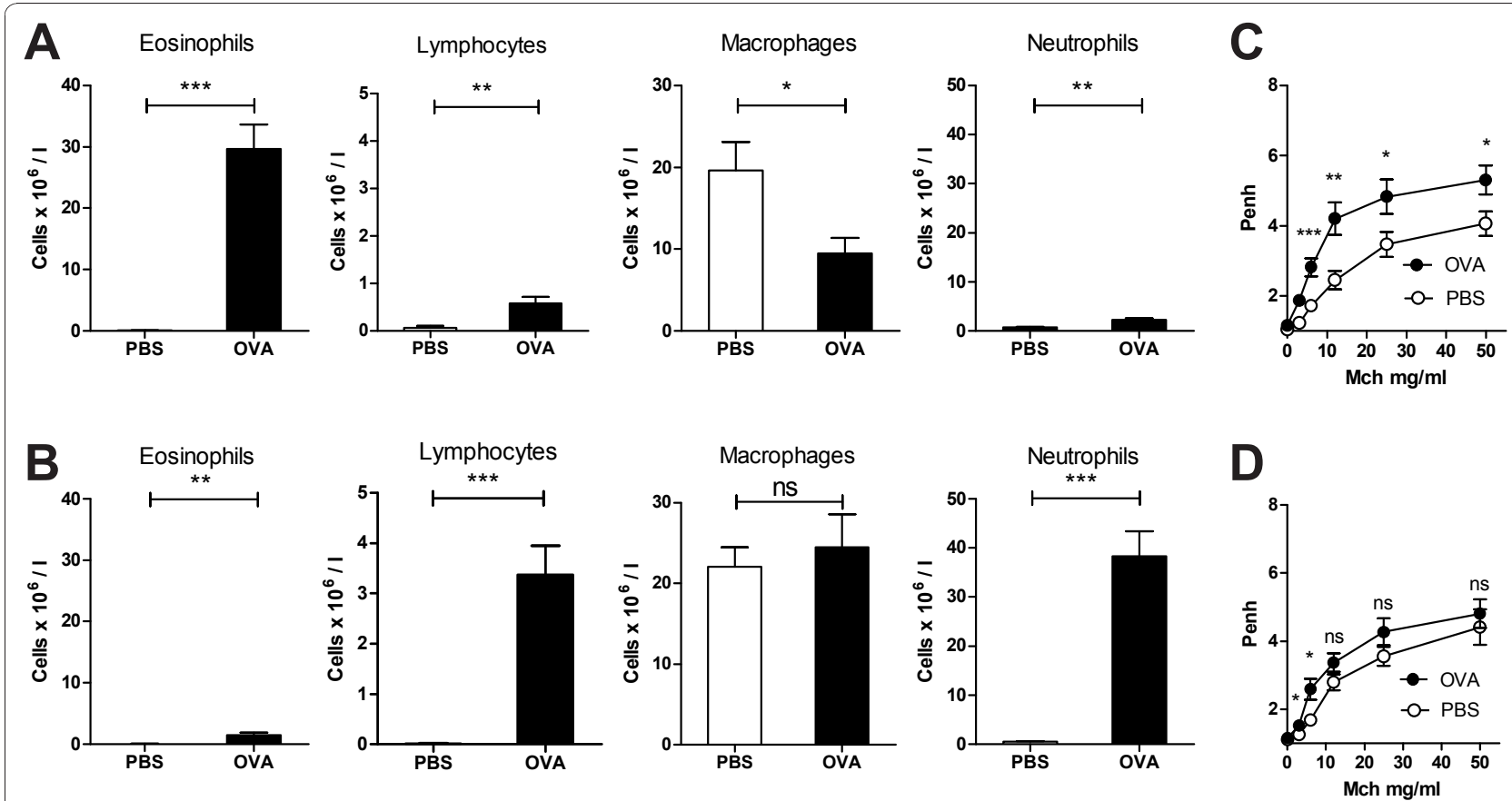

Figure 3 BAL cell counts and the airway hyperreactivity of STAT4-/- and STAT6-/- mice. A-B. Absolute numbers of eosinophils, lymphocytes, macrophages and neutrophils in BAL fluid in STAT4-/- (A) and STAT6-/- (B) mice. C-D. Bronchial hyperreactivity of STAT4-/- (C) and STAT6-/- (D) expressed as enhanced-pause values (Penh) for elevated concentrations of metacholine. RU = relative expression unit. Results are expressed as mean \pm SEM. ${ }^{*} p<0.05,{ }^{* *} p<0.01$, ${ }^{* *} p<0.001$. $n=8$ mice/group, except $n=9$ mice/STAT4-/- OVA group.

expression for tenascin- $\mathrm{C}$ was also elevated after the stimulation with TNF- $\alpha$ and IFN- $\gamma$ for $18 \mathrm{~h}$ in the human primary fibroblasts as well as in the culture supernatant (Figure 6C).

\section{Discussion}

Previous studies have demonstrated that prolonged allergic asthma may lead to structural changes in the airways, which include the modification of extracellular matrix proteins such as tenascin-C. In the present study we investigated the contribution of major Th1 and Th2 transcription factors (i.e. STAT4 and STAT6) to the regulation of expression profiles of tenascin- $C$ in the asthmatic airways of mice. We found similar upregulation of tenascin mRNA and protein in the OVAchallenged WT and STAT6-/- mice. Surprisingly, however, the OVA-challenged STAT4-/- mice showed no increase in tenascin-C mRNA production after allergen challenge, suggesting that STAT4 is an important regulator of tenascin- $\mathrm{C}$ in acute allergic asthma.

Tenascin- $\mathrm{C}$ is expressed both pre- and postnatally in the developing lung [5-7] and is thought to be involved in various inflammatory and fibrotic processes in the adult lung [3]. However, the exact mechanisms are still unknown. In the healthy adult human and mouse lung, tenascin- $C$ is usually absent or its expression is sparse [5-8]. A coding single nucleotide polymorphism (SNP) in the tenascin- $\mathrm{C}$ gene has been linked to asthma in adulthood in the Japanese population [24]. In addition, cyclic strain, which is seen during bronchoconstriction, induces tenascin- $\mathrm{C}$ production through changes in the actin cytoskeleton [25]. Tenascin-C inhibits the contraction of the fibrin-fibronectin matrix implying a central role for tenascin- $\mathrm{C}$ in the modulation of myofibroblast contraction, which is important step in tissue repair [26]. The role of tenascin- $C$ in asthma in vivo is largely unknown but aforementioned mechanisms shed some light on the possible role of tenascin- $\mathrm{C}$ in remodelling. In the present study, our OVA-challenged WT mice showed enhanced expression of tenascin-C in the alveolar structures and veins, whereas in the control mice, tenascin- $\mathrm{C}$ was almost completely absent. Accordingly, the expression of tenascin-C mRNA was higher in the lungs of the OVA-challenged mice than in the control mice. This is in accordance with the results of previous studies that have also shown diminished allergic inflammation in tenascin-C-negative mice [27].

In human adult bronchi, tenascin- $\mathrm{C}$ expression is markedly higher in asthma patients in a stable phase and even immediately after specific antigen challenge $[8,28,29]$. The accumulation of tenascin- $C$ is associated with atopic but not with nonatopic asthma [9,30], and the thickness of the tenascin-C layer correlates with inflammatory cells in the lamina propria in atopic 


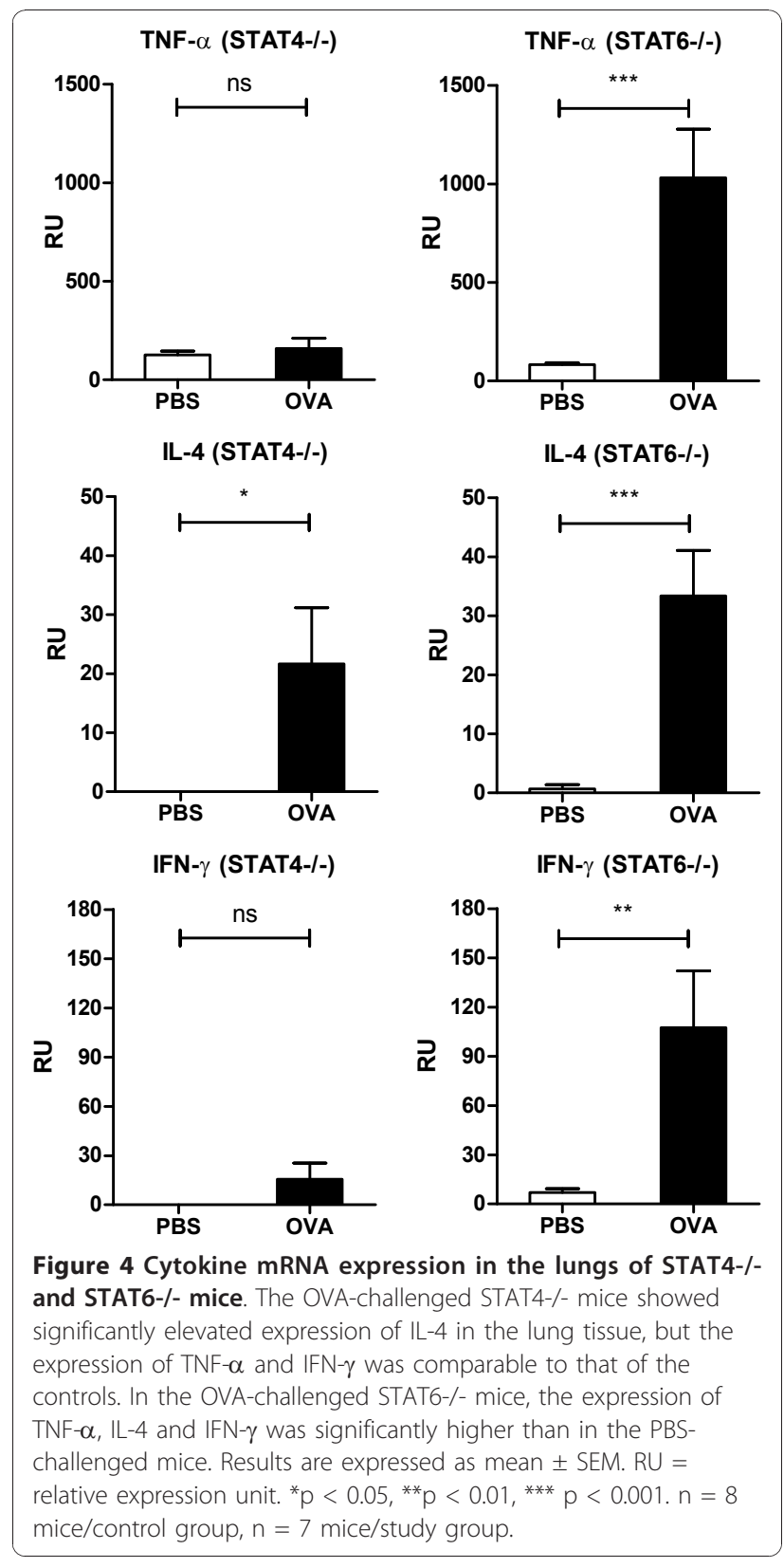

asthma [9]. In the ovalbumin-induced mouse allergy model and in patients with atopic asthma, the Th2 type of inflammation prevails in the airways. Th1 cells, IFN- $\gamma$ and TNF- $\alpha$ are considered important in severe asthma $[1,31]$. No published studies have shown association between asthma severity and tenascin-C expression to our knowledge. To test whether Th1 or Th2 cells are important regulators of tenascin-C expression in experimental allergic asthma, we studied the responses of mice with impaired Th1 (STAT4-/-) or Th2 (STAT6-/-) immunity. To our surprise, our results revealed that tenascin-C expression was normal in STAT6-deficient mice but severely impaired in
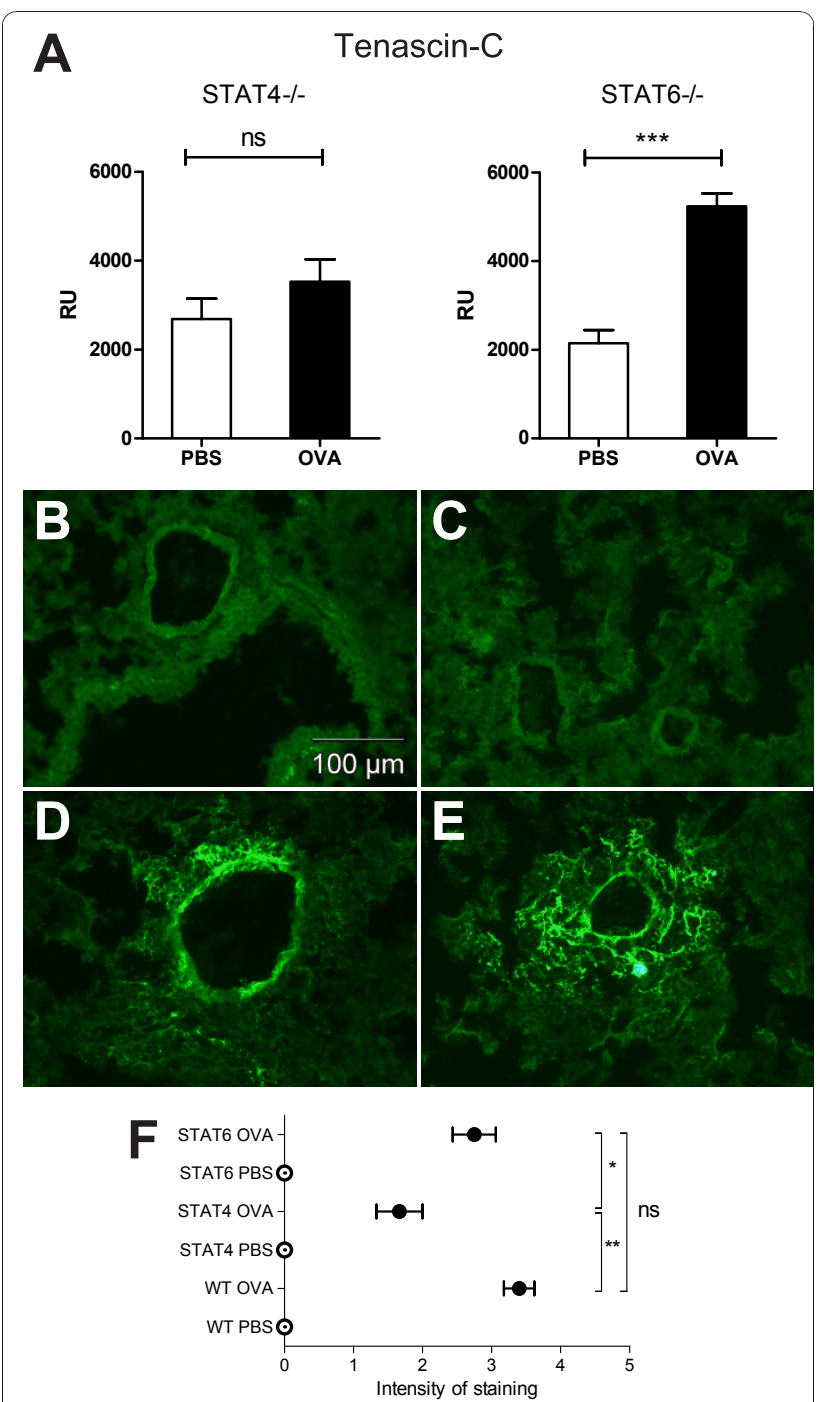

Figure 5 mRNA expression and the immunoreactivity of tenascin-C in the lungs of STAT4-/- and STAT6 -/- mice. (A) The relative mRNA expression of tenascin- $C$ in the lungs of the control ( $n=8$ mice/group) and OVA-challenged ( $n=7$ mice/ group) STAT4-/- and STAT6-/- mice. RU = relative expression unit. Results are expressed as mean \pm SEM. B-E. Immunohistochemical staining of tenascin- $C$ in frozen lung sections. PBS-challenged STAT4-/- (B) and STAT6-/- (C) mice had no tenascin-C immunoreactivity in the lung parenchyma. Lung sections from the OVA-challenged STAT4-/- mice (D) were only weakly tenascinC immunoreactive, while OVA challenge strongly enhanced tenascin-C immunoreactivity in STAT6-/- mice (E). F. The semiquantitative analysis of tenascin- $C$ immunoreactivity in frozen sections. All the PBS-challenged controls were graded negative. OVA-challenged WT mice showed the most intensive expression of tenascin- $C$, although no significant difference was found in comparison with OVA-challenged STAT6-/- mice. In contrast, STAT4-/- mice exhibited a lower intensity of tenascin-C immunoreactivity than STAT6-/- and WT mice. $0=$ no staining, 4 = very strong staining. $\mathrm{n}=10 \mathrm{WT}$ OVA; $\mathrm{n}=9 \mathrm{WT}$ PBS, STAT4-/OVA; $n=8$ STAT4-/- PBS, STAT6-/-PBS, STAT6-/- OVA. Circles represent the mean and the bars indicate the SEM. ${ }^{*} p<0.05$, ${ }^{* *} p<0.01,{ }^{* * *} p<0.001$. 


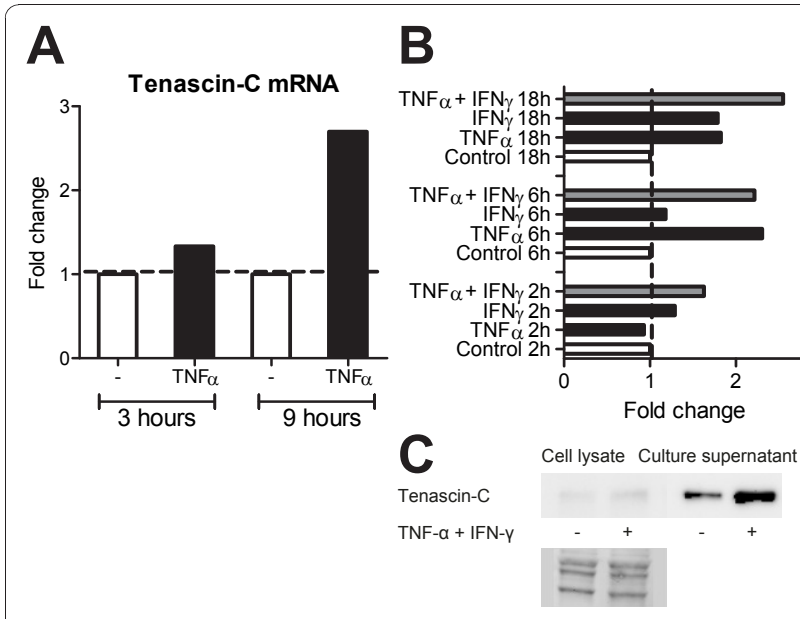

Figure 6 In vitro stimulation of human fibroblasts. A. Recombinant TNF- $\alpha$ increases the mRNA expression of tenascin- $C$ in foetal lung fibroblasts (MRC-9). Expression peaks at 9 hours after stimulation. The results are from one experiment. B. Recombinant TNF- $\alpha$ enhances the mRNA expression of tenascin- $C$ also in human primary fibroblasts. TNF- $\alpha$ along with IFN- $\gamma$ has a synergic effect, which further enhances the expression of tenascin-C mRNA. Control mRNA expressions of tenascin- $C$ are adjusted to 1 and other expressions are shown as the fold change compared to the control. C. An immunoblot showing enhanced expression of protein for tenascin- $C\left(M_{r}\right.$ 290,000 band) in the primary fibroblasts (the first two lanes) and in the cell culture supernatant (the latter two lanes) after stimulation with TNF- $\alpha$ and IFN- $\gamma$ for $18 \mathrm{~h}$. Below SYPRO Ruby staining of the immunoblot confirming equal loading and transfer of proteins from cell lysate samples.

STAT4-deficient mice, thus suggesting that STAT4 plays a critical role in tenascin- $\mathrm{C}$ regulation. IFN- $\gamma$ and TNF- $\alpha$ are known stimulators of tenascin-C expression in bronchial epithelial cells [18], and at least TNF- $\alpha$ in fibroblasts [19]. The low expression of tenascin-C in our STAT4-/- mice may therefore be related to the lack of IFN- $\gamma$ and TNF- $\alpha$ in these mice. This is also in line with our in vitro results, which demonstrated that the stimulation of cultured human MRC-9 fibroblasts with recombinant TNF- $\alpha$ or with TNF- $\alpha$ and IFN- $\gamma$ together from human primary fibroblasts induced the expression of tenascin-C. Thus, the present results suggest that proinflammatory cytokine TNF- $\alpha$ and Th1 cytokine IFN- $\gamma$ released into the airways after allergen challenge critically regulate tenascin- $\mathrm{C}$ expression and may therefore play an important role in initiating the remodelling process of the airways. Our results, together with previous studies that have shown diminished expression of Th2 cytokines in tenascin-Cnegative mice [27], also support the role of tenascin-C as possible mediator of inflammation.

\section{Conclusions}

We conclude that the first steps in the remodelling of the airways are already evident in this mouse acute allergic asthma model. After four weeks of challenge, we found up-regulation of tenascin-C in the WT mice. The STAT4-/- mice exhibited lower mRNA expression for tenascin-C, TNF- $\alpha$ and IFN- $\gamma$ than did the WT mice. This reinforces the role of STAT4 in allergic inflammation in addition to the rather well characterised role of STAT6. The present results are consistent with those of previous reports suggesting that the blocking of STAT6 may make it possible to inhibit allergen-induced AHR responses and pulmonary eosinophilia. However, our results also show that the expression of tenascin- $\mathrm{C}$, a possible early initiator of remodelling, is instead regulated by the STAT4 transcription factor and TNF- $\alpha$ with Th1 cytokine IFN- $\gamma$ in allergic airway inflammation. Moreover, this study, as well as previous ones [32,33] raises the question of the effectiveness of blocking only the STAT6 pathway as a treatment for asthma. The role of tenascin- $\mathrm{C}$ in the diagnosis and treatment of inflammatory airway diseases remains to be explored, but tenascin- $\mathrm{C}$ may be a candidate for an early marker of the remodelling process.

\section{Acknowledgements}

We thank Hanna Wennäkoski for her excellent work with the tissue samples, Rita Haapakoski for her assistance with handling the mice, and Jan-Eric Renholm for his kind assistance with the images. Grants were provided by the Lahja and Väinö Kivi Foundation, the Ida Montin Foundation and the Finnish Medical Foundation.

\section{Author details}

'Institute of Biomedicine/Anatomy, University of Helsinki, Biomedicum, Helsinki, Finland. ${ }^{2}$ Finnish Institute of Occupational Health, Helsinki, Finland. ${ }^{3}$ Laboratory for Clinical Physiology, Helsinki University Central Hospital, Finland. ${ }^{4}$ Division of Allergy, Helsinki University Central Hospital, Finland. ${ }^{5}$ Department of Medicine, Helsinki University Central Hospital, Finland.

\section{Authors' contributions}

AM participated in handling the knockout mice, carried out the RNA studies on the knockout mice, studied the tissue samples from all the mice, participated in analysing the data and designing the study and drafted the article. PK participated in designing the study, handling the knockout mice and drafting the article. ML performed the RNA work, and handled the WT mice and participated in drafting the article. TS performed the human in vitro studies and drafted the article. KS participated in the in vitro studies. M-LM participated in the RNA studies and drafted the article. PP participated in drafting the article. IV participated in drafting the article and helped with analyzing the tissue samples. MM participated in drafting the article. AL participated in designing the study and drafting the article. LAL participated in drafting the article, and HA carried out the design of the study, participated in analyzing the data and drafted the article. All authors read and approved the final manuscript.

\section{Competing interests}

The authors declare that they have no competing interests.

Received: 29 April 2010 Accepted: 4 January 2011 Published: 4 January 2011

\section{References}

1. Holgate ST: Pathogenesis of asthma. Clin Exp Allergy 2008, 38:872-897.

2. Panettieri RA Jr, Covar R, Grant E, Hillyer EV, Bacharier L: Natural history of asthma: persistence versus progression-does the beginning predict the end? J Allergy Clin Immunol 2008, 121:607-613. 
3. Brellier F, Tucker RP, Chiquet-Ehrismann R: Tenascins and their implications in diseases and tissue mechanics. Scand J Med Sci Sports 2009, 19:511-519.

4. Roth-Kleiner M, Hirsch E, Schittny JC: Fetal lungs of tenascin-C-deficient mice grow well, but branch poorly in organ culture. Am J Respir Cell Mol Biol 2004, 30:360-366.

5. Kaarteenaho-Wiik R, Kinnula $V$, Herva R, Paakko P, Pollanen R, Soini Y: Distribution and mRNA expression of tenascin- $C$ in developing human lung. Am J Respir Cell Mol Biol 2001, 25:341-346.

6. Lambropoulou M, Limberis V, Koutlaki N, Simopoulou M, Ntanovasilis D, Vandoros GP, Tatsidou P, Kekou I, Koutsikogianni I, Papadopoulos N: Differential expression of tenascin- $C$ in the developing human lung: an immunohistochemical study. Clin Exp Med 2009, 9:333-338.

7. Saga $Y$, Tsukamoto T, Jing N, Kusakabe M, Sakakura T: Murine tenascin: cDNA cloning, structure and temporal expression of isoforms. Gene 1991, 104:177-185.

8. Laitinen A, Altraja A, Kampe M, Linden M, Virtanen I, Laitinen LA: Tenascin is increased in airway basement membrane of asthmatics and decreased by an inhaled steroid. Am J Respir Crit Care Med 1997, 156:951-958.

9. Karjalainen EM, Lindqvist A, Laitinen LA, Kava T, Altraja A, Halme M, Laitinen A: Airway inflammation and basement membrane tenascin in newly diagnosed atopic and nonatopic asthma. Respir Med 2003, 97:1045-1051.

10. Akimoto T, Numata F, Tamura M, Takata Y, Higashida N, Takashi T, Takeda K, Akira S: Abrogation of Bronchial Eosinophilic Inflammation and Airway Hyperreactivity in Signal Transducers and Activators of Transcription (STAT)6-deficient Mice. J Exp Med 1998, 187:1537-1542.

11. Shimoda K, van Deursen J, Sangster MY, Sarawar SR, Carson RT, Tripp RA, Chu C, Quelle FW, Nosaka T, Vignali DA, Doherty PC, Grosveld G, Paul WE, Ihle JN: Lack of IL-4-induced Th2 response and IgE class switching in mice with disrupted Stat6 gene. Nature 1996, 380:630-633.

12. Ihle JN: The Stat family in cytokine signaling. Curr Opin Cell Biol 2001, 13:211-217.

13. Chiba Y, Todoroki M, Nishida Y, Tanabe M, Misawa M: A Novel STAT6 Inhibitor AS1517499 Ameliorates Antigen-Induced Bronchial Hypercontractility in Mice. Am J Respir Cell Mol Biol 2009, 41:516-524.

14. Darcan-Nicolaisen Y, Meinicke H, Fels G, Hegend O, Haberland A, Kuhl A Loddenkemper C, Witzenrath M, Kube S, Henke W, Hamelmann E: Small Interfering RNA against Transcription Factor STAT6 Inhibits Allergic Airway Inflammation and Hyperreactivity in Mice. J Immunol 2009, 182:7501-7508.

15. Thierfelder WE, van Deursen JM, Yamamoto K, Tripp RA, Sarawar SR, Carson RT, Sangster MY, Vignali DA, Doherty PC, Grosveld GC, Ihle JN: Requirement for Stat4 in interleukin-12-mediated responses of natural killer and T cells. Nature 1996, 382:171-174.

16. Syrbe U, Hoffmann U, Schlawe K, Liesenfeld O, Erb K, Hamann A: Microenvironment-Dependent Requirement of STAT4 for the Induction of P-Selectin Ligands and Effector Cytokines on CD4+ T Cells in Healthy and Parasite-Infected Mice. J Immunol 2006, 177:7673-7679.

17. Raman K, Kaplan MH, Hogaboam CM, Berlin A, Lukacs NW: STAT4 Signal Pathways Regulate Inflammation and Airway Physiology Changes in Allergic Airway Inflammation Locally Via Alteration of Chemokines. J Immunol 2003, 170:3859-3865.

18. Härkonen E, Virtanen I, Linnala A, Laitinen LL, Kinnula VL: Modulation of fibronectin and tenascin production in human bronchial epithelial cells by inflammatory cytokines in vitro. Am J Respir Cell Mol Biol 1995, 13:109-115.

19. Rettig WJ, Erickson HP, Albino AP, Garin-Chesa P: Induction of human tenascin (neuronectin) by growth factors and cytokines: cell typespecific signals and signalling pathways. J Cell Sci 1994, 107:487-497.

20. Jiang $L$, Wei XF, Yi DH, Xu P, Liu H, Chang Q, Yang SM, Li ZF, Gao HB, Hao GJ: Synergistic effects of cyclic strain and Th1-like cytokines on tenascin-C production by rheumatic aortic valve interstitial cells. Clin Exp Immunol 2009, 155:216-223.

21. Makhluf HA, Stepniakowska J, Hoffman S, Smith E, LeRoy EC, Trojanowska M: IL-4 upregulates tenascin synthesis in scleroderma and healthy skin fibroblasts. J Invest Dermatol 1996, 107:856-859.

22. Hamelmann E, Schwarze J, Takeda K, Oshiba A, Larsen GL, Irvin CG, Gelfand EW: Noninvasive Measurement of Airway Responsiveness in
Allergic Mice Using Barometric Plethysmography. Am J Respir Crit Care Med 1997, 156:766-775.

23. Howeedy AA, Virtanen I, Laitinen L, Gould NS, Koukoulis GK, Gould VE: Differential distribution of tenascin in the normal, hyperplastic, and neoplastic breast. Lab Invest 1990, 63:798-806.

24. Matsuda A, Hirota T, Akahoshi M, Shimizu M, Tamari M, Miyatake A, Takahashi A, Nakashima K, Takahashi N, Obara K, Yuyama N, Doi S, Kamogawa Y, Enomoto T, Ohshima K, Tsunoda T, Miyatake S, Fujita K, Kusakabe M, Izuhara K, Nakamura Y, Hopkin J, Shirakawa T: Coding SNP in tenascin-C Fn-III-D domain associates with adult asthma. Hum Mol Genet 2005, 14:2779-2786.

25. Sarasa-Renedo A, Tunc-Civelek V, Chiquet M: Role of RhoA/ROCKdependent actin contractility in the induction of tenascin- $C$ by cyclic tensile strain. Exp Cell Res 2006, 312:1361-1370.

26. Midwood KS, Schwarzbauer JE: Tenascin-C Modulates Matrix Contraction via Focal Adhesion Kinase- and Rho-mediated Signaling Pathways. Mol Biol Cell 2002, 13:3601-3613.

27. Nakahara H, Gabazza EC, Fujimoto H, Nishii Y, D'Alessandro-Gabazza CN, Bruno NE, Takagi T, Hayashi T, Maruyama J, Maruyama K, ImanakaYoshida K, Suzuki K, Yoshida T, Adachi Y, Taguchi O: Deficiency of tenascin $C$ attenuates allergen-induced bronchial asthma in the mouse. Eur J Immunol 2006, 36:3334-3345.

28. Phipps S, Benyahia F, Ou TT, Barkans J, Robinson DS, Kay AB: Acute allergen-induced airway remodeling in atopic asthma. Am J Respir Cell Mol Biol 2004, 31:626-632.

29. Kariyawasam HH, Aizen M, Barkans J, Robinson DS, Kay AB: Remodeling and airway hyperresponsiveness but not cellular inflammation persist after allergen challenge in asthma. Am J Respir Crit Care Med 2007, 175:896-904.

30. Amin K, Ludviksdottir D, Janson C, Nettelbladt O, Bjornsson E, Roomans GM Boman $G$, Seveus L, Venge P: Inflammation and structural changes in the airways of patients with atopic and nonatopic asthma. BHR Group. Am J Respir Crit Care Med 2000, 162:2295-2301.

31. Truyen E, Coteur L, Dilissen E, Overbergh L, Dupont LJ, Ceuppens $J$, Bullens DM: Evaluation of airway inflammation by quantitative Th1/Th2 cytokine mRNA measurement in sputum of asthma patients. Thorax 2006, 61:202-208.

32. Foster PS, Webb DC, Yang M, Herbert C, Kumar RK: Dissociation of $T$ helper type 2 cytokine-dependent airway lesions from signal transducer and activator of transcription 6 signalling in experimental chronic asthma. Clin Exp Allergy 2003, 33:688-695.

33. Zimmermann N, Mishra A, King NE, Fulkerson PC, Doepker MP, Nikolaidis NM, Kindinger LE, Moulton EA, Aronow BJ, Rothenberg ME: Transcript Signatures in Experimental Asthma: Identification of STAT6Dependent and -Independent Pathways. J Immunol 2004, 172:1815-1824.

doi:10.1186/1465-9921-12-2

Cite this article as: Meuronen et al:: Attenuated expression of tenascin-c in ovalbumin-challenged STAT4-/- mice. Respiratory Research 2011 12:2.

\section{Submit your next manuscript to BioMed Central and take full advantage of:}

- Convenient online submission

- Thorough peer review

- No space constraints or color figure charges

- Immediate publication on acceptance

- Inclusion in PubMed, CAS, Scopus and Google Scholar

- Research which is freely available for redistribution

Submit your manuscript at www.biomedcentral.com/submit
C Biomed Central 